\title{
Buddhist Psychology, Mind And Consciousness
}

\section{Upadhyaya KD}

\author{
Consultant Psychiatrist Kathmandu Model Hospital \& Advisor, Community Mental health and \\ Counseling $(C M C-N)$ Nepal.
}

E-mail *Corresponding author : drkapilupadhyaya@gmail.com

Modern psychology or western psychology is little more than a century old. At the beginning of the twentieth century, William James became Harvard's first professor of psychology. In the east Buddhism, Hinduism and Jainism based practices of consciousness, and meditation were there for many centuries for liberation. But in the west beginning with Freud himself, altered state of consciousness, was considered as a psychopathology. After the discovery of neurotransmitters in the brain, scientists were mainly focusing on their functions and usefulness. Some people who were interested in eastern philosophy, psychology, spirituality and meditation came to Thailand, Myanmar, India and Nepal and practiced meditation under the teachers' guidance. They also learned the eastern view of meditation, consciousness and mind. Those who were highly influenced by Buddhist psychology, teachings and meditations later became psychologists, teachers, and scientific researchers. They wrote many books on Buddhism, and meditation.

William James was an American philosopher and psychologist, and the first educator to offer a psychology course in USA. He is known as the Father of American psychology. Mark Epstein, a psychiatrist who has written a very popular book " Thoughts Without a Thinker writes there "James was impressed with the psychological sophistication of Buddhism and predicted that it would be a major influence on western psychology."1

Arnold J Toynbee a British historian and Philosopher declared that the arrival of Buddhism in the West " may well prove to be the most important event of the twentieth century".

James prediction is already seen in the west. Western psychologists and psychiatrists are highly influenced by Buddhist psychology. Researches are going on to find the effects of meditation on long-term meditators, use of Buddhist psychology in the treatment of neurotic disorders and depression, and in social, emotional and ethical learning in school education. Many books have been written in Buddhism in Sravakayana, Mahayana, and Vajrayana based on Buddha's teachings. This article is written just to summarize in brief about Buddhist psychology as an introduction.

Abhidharma provides the philosophical basis of Buddhist psychology and includes analysis and classification of the nature of consciousness and mental functioning.

In Buddhist psychology there are eight levels of consciousness. Five of them are sense consciousness like; Visual consciousness, Auditory consciousness, olfactory consciousness, gustatory consciousness and tactile consciousness. Sixth is mental consciousness, seventh is Manas consciousness and eighth consciousness is store consciousness (equivalent to subconscious mind). Store consciousness is both individual consciousness and collective consciousness.

The Buddha taught that "I" is a combination of our form or physical body, our feelings, our perceptions, our mental formations and our consciousness. These are called five skandhas (aggregates). These five elements are like the five rivers all the time flowing or changing. According to Buddhist philosophy, everything is impermanent, and there is constant change in everything including us from moment to moment. So there are physical and mental energies in us and they are constantly changing in every moment and there is no permanent unchanging self or Atamn. A mental formation means fear, hate, jealousy, love, understanding, compassion, hope and so on. Consciousness is like the soil in which the seeds of mental 
formations are preserved. Consciousness depends on matter, sensation, perception, and mental formations. So there is no arising of consciousness without conditions.

Our genes are like the seeds in our store consciousness. So store consciousness is within each cell of our body ${ }^{2}$. Store consciousness has three functions; store and preserve all the seeds (bija) of our experiences, the seeds themselves and store for the attachment to self. It is interesting to note that Tibetan point the heart as the seat of mind, and Occidentals point the seat as the brain ${ }^{3}$. Cosmic consciousness is a higher form of consciousness, than that possessed by the ordinary man.

Sigmund Freud's unconsciousness corresponds to the Buddhist concept of the store consciousness. Seventh consciousness, Manas, is more or less equivalent to the notion of ego of psychoanalytical school. Freud's superego has some affinity to mind consciousness or sixth consciousness.

According to Buddhist view, Chitta, Mana, Awareness, Vijgyan, Clarity and Consciousness means mind. Mind has no form, no colour, and no substance. So mind cannot be seen. But mind can know things and perceive an infinite variety of phenomena. Thoughts, feelings, sensations, perceptions and experiences are part of the mind. Aware of awareness is also mind or chitta. Knowing one's own awareness is really the heart of mindfulness according to Tsoknyi Rinpoche ${ }^{4}$.

Buddhist consciousness is divided into gross, subtle and very subtle state of consciousness. Generally we are grossly conscious, in deep meditation mind is in subtle state, and very subtle state is experienced only in death. The mind at the time of being awake is coarse, when dreaming it is subtle and in dreamless deep sleep it is very subtle.

According to Highest Yoga Tantra ${ }^{5}$ the coarse minds are the sense consciousness, the subtle mind is the conceptual mental consciousness and very subtle mind is the mind of clear light.

Gross consciousness or energy-wind corresponds to normal daily awareness with its emotional life and thought process. Subtle consciousness or energy-wind relates to the inner feelings and emotional under currents, the contents are believed to be unconscious. Subtle body is often called emotional body. The very subtle consciousness or energy-wind relates to clear light, innate wisdom or Buddha Nature This energy-wind is also known as the life supporting wind.

When we talk about consciousness, it is mental consciousness. Mental consciousness never stops and it is clear, sensory consciousness can stop. Here clear means knowing. Sensory consciousness often overrides mental consciousness, unless one is very alert. When we are in a dark room, mental consciousness knows that it is dark, this is knowing. This darkness is clearly visible, this is luminosity. Luminosity does not mean white, it means clarity ${ }^{6}$.

Consciousness occurs uninterruptedly throughout all of one's worldly lifetime. It descends into the mother's womb at the beginning of each life and departs at its end 7 . This process continues till the cycle of birth and death, and ends with Nirvana. Cognitive awareness for human beings is analyzed in terms of six specific modalities - visual, auditory, olfactory, gustatory, tactile and mental cognitive awareness based on the five senses and mind. Buddhist psychology considers mind also a sense organ, so there are six sense organs. According to Buddhism, ignorance is the main cause of cycle of birth, death and rebirth. Rebirth is neither the exact same person nor a completely different person, as everything is impermanent and changing from moment to moment. Ignorance is explained as; regarding impermanent as permanent, suffering as pleasure and non-self as self. Birth, sickness, old age and death, are suffering but this truth is often forgotten. Dukkha means dissatisfaction, dis-ease and suffering.

In Buddhism, the mind of a man, the consciousness of man is very often compared with water in its pure, translucent and sparkling state. The mind that is under the power of craving is compared with water in which dyes have been mixed; due to which purity of the mind is lost. When there is hatred in the mind, it is like water at boiling point, bubbling and giving off steam. When we are angry, we sometimes let off steam and scald ourselves as well as other people.

To understand mind well, Buddhist teachings make a distinction between Natural Mind and ordinary mind. Ordinary mind is unpredictable and frequently out of control mind. The Buddha 
described Natural Mind as still, clear, lucid, empty, profound, simple and at peace ${ }^{8}$.

The Buddha's lesson for all of us is that happiness cannot be found in sensual gratification like more money, sex, vacations, status, pride etc. The Buddha also taught that a life devoted to self-denial, self-blame and guilt is equally misdirected.

In Buddhism, birth is suffering, decay is suffering, disease is suffering, death is suffering, sorrow, lamentation, pain, grief and despair are suffering, to be united with the unpleasant is suffering, to be separated from the pleasant is suffering and not to get what one wants is suffering. In brief the five aggregates of attachment are suffering'.

Through the decades, there have been claims that Buddhism is science, that the Buddha was the founder of psychology, that the Buddhism discovered the size of elementary particles and the universe, that the modern physics merely confirms what Buddhist sages knew centuries ago. ${ }^{10}$

After more than a century of looking for it, brain researchers have long since concluded that there is no conceivable place for a self to be located in the physical brain, and that is simply does not exist ${ }^{11}$.

Let us try to understand this classic Buddhist collection of verse, the Dhammapada:

I wandered through the rounds of countless births, Seeking but not finding the builder of this house.

Sorrowful indeed is birth again and again.

Oh, housebuilder! You have now been seen.

You shall build the house no longer.

All your rafters have been broken,

Your ridgepole shattered.

My mind has attained to unconditional freedom.

Achieved is the end of craving. ${ }^{12}$

The whole of Buddhist Psychology is encapsulated in this verse but not so easy to understand .

\section{REFERENCES:}

1. Marks Epstein , MD ;Thoughts without a Thinker Psychotherapy from a Buddhist Perspective. Basic Books. 1995.p 1.

2. Thich Nhat Hanh: Understanding Our Mind: Harper Collins India pp 23 - 24

3. Keith Dowman: The Flight of the Garuda, 2014. Wisdom Publication pp192.
4. Open Heart, Open Mind: A Guide to inner Transformation. Tsoknyi Rinpoche. Pp 115

5. Highest Yoga Tantra: Daniel Cozort; Snow lion Publication pp 96.

6. Mahamudra by Geshe Dorji Damdul (youtube no.6)

7. William S Waldron: The Buddhist Unconsciousness pp38. Routledge Curzon 2003.

8. Lama Surya Das: Awakening the Buddha within. Broadway Books, New York 1998. p-316.

9. Marks Epstein, $M D$;Thoughts without a Thinker Psychotherapy from a Buddhist Perspective. Basic Books. 1995.p.46

10. Sharon Begley. Train Your Mind Change Your Brain; Ballantine Books New York. p-12

11. Lemonick, M. D. (1995, July 17). Glimpses of the mind. What is consciousness? Memory? Emotion? Science unravels the best-kept secrets of the human brain. Time. Retrieved February 9, 2009, from http://www.time.com/time/classroom/psych/unit3_artic le1.html

12. Joseph Goldstein and Jack Kornfield, Seeking the Heart of Wisdom: The Path of Insight Meditation. Boston: Shambhala, 1987,p.83 